\title{
Introduction to The Harvard Lectures of Alfred North Whitehead, 1924-1925
}

\author{
Paul A. Bogaard, Hart Massey Professor of Philosophy, \\ Emeritus, Mount Allison University
}

On February 6, 1924, the President of Harvard University, A. Lawrence Lowell, wrote to Whitehead, asking whether he would accept an appointment as Professor of Philosophy for five years....

Thus begins the 'Migration to Harvard' chapter of Victor Lowe's biography of Whitehead, detailing the steps leading to this formal offer and its aftermath. It marked the transition out of a career devoted to teaching mathematics and mathematical physics. It led into an extended career, well beyond five years, devoted to philosophy. This volume of lectures reflects the first step in that transition.

When Whitehead received this formal invitation he was days away from turning 63. A full career already lay behind him: 26 years as a Fellow at Trinity College, Cambridge, another 13 years teaching applied mathematics and serving in administration at the University of London, with over 50 books, articles and presentations to his credit. ${ }^{2}$ Nevertheless, Whitehead was not yet ready to retire.

The Chairman of the Philosophy Department assured Whitehead that they would arrange plans within the department 'so that you could give your energy to the problems which interest you the most'. That might include a lecture course on the philosophy of science and one evening a week devoted to discussion of metaphysics and logic with graduate students. ${ }^{3}$ When his wife asked him about this invitation to Harvard, Whitehead is said to have responded: 'I would rather do that than anything in the world'. ${ }^{4}$

They crossed from old England to New England in August and by 25 September Whitehead had plunged into the first course of philosophy lectures he had ever given. For these lectures he chose the title: 'The Philosophical Presuppositions of Science'. Within the departmental course listings it was

1. Victor Lowe, Alfred North Whitehead: The Man and His Work, Volume 2 (Baltimore: Johns Hopkins University Press, 1990), p. I32.

2. See the chronology of Whitehead's life (pp. xvii-xix) and the chronological list of his publications (pp. $\mathrm{xx}$-xxiv) provided in the present volume.

3. From the letter sent by Professor Woods quoted by Lowe, Volume 2, p. 135.

4. From the account of Lucien Price as quoted by Lowe, Volume 2, p. I35. 
'Phil $3 b$ ' and it extended through both 'halves' of the year. ${ }^{1}$ Arrangements were made for Whitehead to teach this course in Emerson Hall within Harvard Yard, and also at Radcliffe under the same course listing and title - likely in Fay House. ${ }^{2}$ As Whitehead wrote to his son, North, on 9 November that year: ${ }^{3}$

Tuesdays, Thursdays, Saturdays are my lecture mornings, viz. 9-10 at Radcliffe (repetition of Harvard course) and I2-I at Harvard in Emerson Hall ... they are 50 minute affairs.

He describes for North how he made his way through these teaching days and provides a glimpse of each class, first at Radcliffe and then in Emerson Hall:

My class at Radcliffe has 9 or Io members -4 undergraduates, or postgraduates, taking it for 'credit' as the phrase is, and the others 'auditors' in the technical language used here. They are an intelligent set of young people.

One of these postgraduate students, Louise R. Heath, kept the notes she took from the course of lectures as delivered by Whitehead at Radcliffe. As for Emerson Hall:

At my twelve o'clock lecture the audience is just $40-$ mostly postgraduate and including about to members of the staff. I think that they are interested ... and the audience has rather increased lately. At the end of the lecture men come up and ask questions. ${ }^{4}$

A senior colleague, William Ernest Hocking, attended many of these Emerson Hall lectures, beginning about a month into the semester, and kept his own notes. Both the Heath notes from Radcliffe and Hocking's from Emerson Hall have been known about for some time. What has been discovered only within recent years is that a younger colleague, Winthrop Pickard Bell, attended nearly all of the Emerson Hall lectures and his extensive notes have been preserved. Transcriptions of these three sets of notes form the major part of this volume.

There was also Whitehead's graduate seminar, Phil $20 \mathrm{~h}$, 'Seminary in Metaphysics', during the first semester only:

On Fridays there is the Seminary 7:30-9:30 in the evening. About 17 or 20 men, including some of the staff. I arrange for a student to read a paper, and we discuss it. I usually start the discussion, and intervene at irregular intervals. It is great fun. The men really discuss very well, with great urbanity and desire to get at the truth.

1. Although course numbers at Harvard often distinguished 'a' from ' $b$ ' depending on the semester in which a course was taught, Whitehead's course of lectures at both Radcliffe and in Emerson Hall was 'Phil 3 b' and was offered through both semesters.

2. As we were told when enquiring at the Radcliffe Archives in March 2015.

3. Letters from Whitehead to his son, North, from August 1924 to August 1929 were transcribed and printed as Appendix B, to Lowe's Volume 2. That for 9 November 1924 appears on pp. 294-7.

4. Whitehead refers to 'men' at his Emerson Hall lectures, while we think it was women only at the Radcliffe lectures; although a formal list of graduate students (and colleagues) has not been found for the Friday evening 'Seminary', it seems to have included both men and women. 
The following semester there was a 'Seminary in Logic' about which Victor Lowe managed to glean some information, although no notes have been found. ${ }^{5}$ But for his Seminary in Metaphysics we do have notes from a few of these first-semester Friday evenings, written once again by Hocking. Notes for only a portion of the semester were found among Hocking's papers, ${ }^{6}$ but those that have been found have been included in this volume.

So, we know quite explicitly what Whitehead was teaching at Harvard (including both at Emerson Hall and at Radcliffe), which matches what the department had asked of him at the beginning of the year. It was his first opportunity to explore his philosophical thoughts in the classroom. The lectures mark a major transition in his life and stand at a crucial juncture in his thinking. Especially since there are no remaining manuscripts of works that Whitehead published soon after this transition to New England, the two major ones being Science and the Modern World later in 1925 and Process and Reality in 1929, these lectures represent the only opportunity to gauge his ever-developing thoughts at this stage, and how these thoughts were growing beyond his earlier philosophical works: An Enquiry Concerning the Principles of Natural Knowledge (1919), The Concept of Nature (1920) and The Principle of Relativity, with Applications to Physical Science (1922). Assessing the importance of these lectures will now be possible, largely thanks to the efforts of his students and colleagues, and in remarkable detail. How has this come about?

\section{Winthrop Pickard Bell ${ }^{7}$}

Of the three people upon whom this volume depends for a window into Whitehead's teachings during his first academic year at Harvard, Winthrop Bell is the most extraordinary for the unexpected thoroughness of the notes he kept, and for the twists and turns that brought him to Whitehead's classroom in Emerson Hall. Both of these points require some explanation, and both present challenges.

Unexpected, because Bell's are not the typical notes one might expect to be taken to record university lectures. They are consistently thorough, to the point of providing an almost complete record of everything said that day - from beginning to end, including asides, jokes, reading and essay assignments - and a careful rendering of equations, diagrams and logical formalisms (in Principia Mathematica notation) copied from the blackboard. ${ }^{8}$

5. Lowe, Volume 2, p. I47.

6. Now held at Houghton Library, Harvard - see page li.

7. This section relies directly upon the 'Biography of Dr. Winthrop Pickard Bell' at the outset of the Winthrop Bell Virtual Exhibition located on the website of the Mount Allison University Archives, and the extensive work by Jason Bell (no relation) on W. P. Bell's years at Göttingen. See, for example, Jason Bell, 'Four originators of transatlantic phenomenology: Josiah Royce, Edmund Husserl, William Hocking, Winthrop Bell', in Kelly Parker and Jason Bell (eds), The Relevance of Royce (New York: Fordham University Press, 20I4), pp. 47-68.

8. The Appendix to this volume provides sample pages scanned from the original handwritten notes kept by Bell, Hocking and Heath. 
Was Whitehead's course of lectures the only example of Bell taking this amount of care? We can dispel that immediately by pointing out that during the same time, namely from October 1924 through to January 1925, Bell kept notes of the course of lectures for Phil I2c, 'The Philosophy of Aristotle', presented by Professor James H. Woods. There were no equations or logical notation, to be sure, but the same tiny handwriting similarly captured these lectures in full, replete with Greek in classical polytonic orthography. The best answer to when and how Bell developed this remarkable technique for taking notes is found early in his academic career.

However, Winthrop Bell's academic career was brief. After a promising beginning, with quite enviable opportunities, Bell nevertheless resigned from Harvard after teaching there only five years. His promising dissertation was never published (until recently rediscovered ${ }^{1}$ ) and his notes, papers and extensive correspondence were all taken with him back to his Nova Scotia home. And there they remained until a few years ago. How did it come to this?

Winthrop Pickard Bell (I884-1965) was born in Halifax to a prominent Canadian family: his father, Andrew, was a wealthy merchant and personal friend of the future Canadian Prime Minister Sir Robert Laird Borden (Borden would later request Winthrop Bell's services as his political interpreter at the Versailles treaty meetings); his maternal grandfather, Humphrey Pickard, was the founding President of what has become Mount Allison University; his brother Ralph served as Secretary of the Halifax Relief Commission after the Halifax Explosion of 1917 and served as Chancellor of Mount Allison University between 1960 and 1968.

Winthrop Bell's path into the academic world followed what was already a family tradition: a bachelor's degree in mathematics from Mount Allison in 1904, with honours, and a master's degree from Mount Allison in 1907 specialising in philosophy, history and German. Family wealth made possible his gaining a master's degree in philosophy from Harvard University in 1909; further graduate studies followed at Cambridge University, I909-IO, and in Germany at the University of Leipzig, I9IO-II, and then at the University of Göttingen, I9II-I4, although his PhD from Göttingen was delayed until 1922.

These years of delay were brought on by two unexpected twists: the declaration of war in I9I4 found Bell not just unable to leave, but an 'enemy citizen' consigned to various German prisons for nearly the entire duration of the war, for the most part at Ruhleben. Even then, when peace was restored, Bell's papers reveal that he filed secret military reports on the political situation in Europe on behalf of the British and Canadian governments, activities for which he would, years later, be offered to become a Member of the Order of British Empire (an honour which he declined). Only thereafter did he return to North America, initially to his home in Nova Scotia; for the academic

1. It was Bell's complete doctoral dissertation that Jason Bell first realised was among the papers now kept in the Bell Fonds at Mount Allison University Archives. It is being published as: Husserliana Dokumente, Volume 5, Winthrop P. Bell. Eine kritische Untersuchung der Erkenntnistheorie Josiah Royces. Dissertation I9I4/22, through the Husserl Archives at Leuven. 
year I92I-2 he taught philosophy at the University of Toronto; and in I922, with his $\mathrm{PhD}$ reinstated by Göttingen, he was appointed to the Department of Philosophy at Harvard University as 'Instructor and Senior Tutor'. By the end of his second year, his diary records that not only was he tutoring and teaching but he was also a reader for several $\mathrm{PhD}$ theses, including that of Charles Hartshorne. ${ }^{1}$ During the $1924-5$ academic year - the year Whitehead began his appointment - Bell shared his status in the department with Raphael Demos and Ralph Eaton. They each tutored and examined the students taking the basic Phil A course, for which J. H. Woods, R. B. Perry and W. E. Hocking provided the lectures. Each of them also taught a course of his own. It was Demos on whom Whitehead relied to do the examining of students taking Phil $3 \mathrm{~b},{ }^{2}$ the course on which Bell kept his extensive notes.

In 1927, to everyone's surprise, Bell resigned from Harvard and returned to Nova Scotia. ${ }^{3}$ This curtailed any plans for completing a book already begun ${ }^{4}$ but he did maintain contact with Harvard colleagues, had become good friends with Whitehead's son North, and maintained an extensive correspondence with Göttingen's phenomenological circle: Edmund Husserl, Edith Stein and many others. He was thereafter primarily engaged in business activities. During World War II, Bell lent his skills to the Canadian government to help constitute Canada's aircraft defences; he was elected Regent of Mount Allison in 1948; he was elected President of the Nova Scotia Historical Society in I95I; and he published a widely acclaimed work of local history, The 'Foreign Protestants' and the Settlement of Nova Scotia, in 1961. He died on 4 April 1965 in the province of his birth, in rural Chester, Nova Scotia, by the sea, at the age of 80 .

Before we turn to the fate of Bell's books and papers, we must look a little more closely at his time in Göttingen. As a doctoral student between I9II and I9I4, during a peak period of the phenomenological movement, Bell attended several of Edmund Husserl's courses. In August I9I2 Bell was invited to present an official seminar summary and Husserl was so impressed by the result that he asked to supervise Bell's dissertation. Here is an opportunity to shine light on the surprising level of detail that is found in Bell's transcriptions. Husserl (by Bell's own account to Herbert Spiegelberg, in 1955) initially asked Bell to put his pen down: he was taking too many notes and he should rather simply listen to see how phenomenology works.

1. Transcription of the 1924 diary by David Mawhinney, Bell Fonds, $8550 / 5 / 5$.

2. Lowe, Volume 2, pp. 139-40.

3. Bell kept up correspondence with Demos for many years. A letter to Bell in 1930 from Zurich, where both Demos and Eaton were recuperating, reads: 'Well, Winthrop, you cleared out in time. I never thought the Harvard Phil Dept could run without us three - anyway, in the undergraduate part'. And a year later: 'It is a problem, I see, to be a philosopher and save your soul at the same time'. Bell Fonds, $8550 / \mathrm{I} / \mathrm{I} 5$, no. 4 and no. 6 .

4. Decades later, Bell had apparently taken Husserl's defence of Royce to heart, writing: 'If I had ever finished the book I at one time had partly written, what is valuable in my dissertation would have been incorporated therein'. Bell to Hocking, 22 April 1957, William Ernest Hocking Collection, Houghton Library, Harvard University. 
Yet for Bell, taking so many notes, and reviewing them later, was how he learned. Bell continues:

It came to the last meeting but one. Now, said Husserl, we have had a good semester's work here. I think we should have for our last meeting a summary of the whole thing. 'Wer möchte das unternehmen? - Ach, Herr Bell! Sie haben immer so fleißig mitgescrieben. Ich glaube, Sie haben sich dazu bestimmt!' [Who would like to undertake this? Ah! Mr Bell! You have always so diligently written. I think you are the right one for the work!] ... I managed to please not only Husserl, but apparently the members of the seminar... Then he said that if I wanted to do a Doktorarbeit under him I might come and see him at the beginning of the winter semester. It was an extraordinary piece of luck in every way - that he should have picked on me because of something he disapproved of, and then that the work of that semester's seminar had just been something that I should summarize with real satisfaction to myself and at the same time in a way that pleased him. ${ }^{1}$

Husserl's initial objection, that Bell wrote too much, points to Bell's skill as a recorder at both the early stages of phenomenology but also at the crucial transition towards Whitehead's process metaphysics. Likewise, Husserl's deeply positive impression with Bell's extensive notes mirrors our good fortune in 'hearing' Whitehead's lectures through Bell's extraordinary detail.

Bell's Göttingen studies occurred during a particularly formative time in the constitution of phenomenology. As Bell later recalled to Hocking:

My experience was just at the time of some of [Husserl's] most intense absorption in his own work, in 1912-1913, when he was writing the first installment of his Ideen for the forthcoming Jahrbuch. He even, if I remember aright, had his meals served to him in his study, so that his trains of thought should not be interrupted by the conversation at the family table. ${ }^{2}$

Husserl was keen to build on Bell's familiarity with Josiah Royce ${ }^{3}$ :

Having sat under Royce at Harvard a couple of years earlier I was able to talk more or less enlighteningly on his name. Husserl asked to see some of his works ... [he] then would have nothing else than that I should do my Doktorarbeit on Josiah Royce. ${ }^{4}$

Despite an initial hesitation, Bell took up the task with his usual thoroughness, and Husserl termed Bell's dissertation an 'ausgezeichnet ...

1. Bell to Spiegelberg, I7 December 1955, Bell Fonds.

2. Bell to Hocking, 6 January 1962, Hocking Collection.

3. Josiah Royce (1855-1916) was born in California and spent nearly the entirety of his career as Professor of Philosophy at Harvard University. He defended a version of idealistic pragmatism, termed by him 'Absolute Pragmatism', against the comparatively individualistic pragmatism advanced by his personal friend and philosophical critic William James. Royce has been noted in recent scholarship as a progenitor of process and phenomenological philosophy. In addition to supervising Winthrop Bell's work on the master's degree, among Royce's notable students were George Santayana, T. S. Eliot, C. I. Lewis and William Hocking; Charles Hartshorne cites Royce as an early influence.

4. Bell to Spiegelberg, 25 September 1955, Bell Fonds. Correspondence from Bell to Hocking shows that Bell lent to Husserl Royce's collected works for a period of at least several years, and that he underlined key passages for Husserl. Bell later donated these books to Mount Allison University. 
excellente Einleitung in die phänomenologische Erkenntnistheorie' ${ }^{1}$ [a 'distinguished, excellent introduction in phenomenological epistemology'] which contained 'viel Schönes'. ${ }^{2}$ Husserl sought to publish this work in the Jahrbuch für Philosophie und phänomenologische Forschung. It is finally appearing, over a century later, in the 'Husserliana Dokumente' series, along with Husserl's extensive commentary. Yet, why has it remained for so long unpublished? The answer to this may also help to shine some light on why Bell's other works, including his transcription of the Whitehead lectures, have so long remained unknown.

The conditions on 7 August 19I4, the day when Husserl and the committee conducted Bell's oral examination, and promoted him with honours, were very far from ordinary. As Bell reports:

I was caught in Germany by the outbreak of the First World War. In fact, my oral examination took place after the war had broken out, and under most unusual circumstances. I was in 'protective custody', having been hauled out of bed in the middle of the night when England declared war. ${ }^{3}$

Bell, as a Canadian citizen, was a British subject and hence an enemy alien in Germany. The university annulled Bell's doctorate and it was therefore quite impossible to publish the work at that time.

In 1922, Göttingen re-awarded Bell the doctorate, he took up his position at Harvard, and Husserl was finally in a position to offer to publish the dissertation in the Jahrbuch. Yet eight years after the completion of his work, Bell felt himself distanced from his criticisms of Royce, even as he remained in agreement with the essence of the work. Since in his later historical writings Bell showed himself to be something of a perfectionist, this might have been one element in his turning down Husserl's offer to publish the work. Husserl was certainly disappointed: 'es ist doch schade, dass Ihre Dissertation liegen bleiben soll. Hier dient sie mir gelegentlich als Lehrmittel'4 ['It is a pity that your dissertation shall remain unpublished. It has served me here (in Freiburg) as a teaching aid'].

It is interesting to note that Husserl, the founder of the modern phenomenological movement, called Bell his 'weiser Mentor und Mithelfer's his wise friend and co-worker. As the first Anglophone doctoral student of Husserl's phenomenology, Bell introduced Husserlian phenomenology into the English language, as the first North American professor of phenomenology both in Canada (at Toronto), between I92I and $1922,{ }^{6}$ and

1. Husserl's letter to Bell of I4 May 1922, Bell Fonds. Also published in Edmund Husserl, Briefwechsel (Husserliana: Edmund Husserl Dokumente 3/3, ed. Karl Schuhmann) (Dordrecht: Kluwer Academic, 1994).

2. Letter from Husserl to Bell, 30 September 1922, Bell Fonds.

3. Bell to Spiegelberg, 25 September 1955, Bell Fonds.

4. Husserl to Bell, I3 December 1922, Bell Fonds. Also published in Husserl, Briefwechsel.

5. Husserl to Bell, 7 December I92I, Bell Fonds. Also published in Briefwechsel, p. 30.

6. Upon this appointment, Husserl wrote to Bell (I4 May 1922): 'Sie müssen doch ein famoser phänomenologischer Lehrer sein, in Ihrer übrigens echt englischen anschaulichen Sprache und präcisen Linienführung'. Bell Fonds. Also published in Husserl, Briefwechsel. 
in the United States (at Harvard), between 1922 and 1927. ${ }^{1}$ At Harvard, Bell taught the phenomenological method in graduate seminars that included such future Husserl students as Charles Hartshorne and Dorion Cairns, both of whom credited Bell for their introduction to Husserl. Indeed, Hartshorne would later be counted among those who were deeply influenced not only by Husserl but also by Whitehead.

\section{William Ernest Hocking}

Hocking's story is interwoven, if loosely, with Bell's. Almost Io years before Bell's arrival in Göttingen Hocking had studied there, and may even have introduced to Husserl the idea of there being affinities between his recent Logical Investigations (I9OI) and aspects of the work of Josiah Royce, with whom Hocking had studied at Harvard. A curious thought, that the two colleagues each taking notes during the same lectures in 1924-5 had these features of their prior studies in common. More than that, Hocking had played a role in transmitting Husserl's recommendation for Bell to the Harvard department supporting Bell's appointment. One imagines them sitting side by side in Whitehead's lectures, responding each in his own way.

William Ernest Hocking (1873-1966) was born in Ohio and had studied engineering at Iowa State University before turning to philosophy. He studied under Royce at Harvard beginning in 1899 and completed his master's degree in I90I. The first American to study with Husserl at Göttingen, Hocking also studied in Berlin and Heidelberg before completing his PhD back at Harvard in 1904. His early years teaching were at Andover Theological Seminary, Berkeley and Yale before returning to Harvard in I9I4.

Bell had also studied engineering for a time at McGill via Mount Allison and prior to his entering Harvard. But despite this sequence of similarities, the timing of these two careers was such that when Bell was studying at Harvard, Hocking was teaching elsewhere. And by the time Bell arrived in Göttingen, Hocking had returned to Harvard to join the staff. They were

1. Husserl successfully recommended Bell for the position at Harvard, writing to his former student Hocking, now a professor at Harvard, that Harvard would be well served by Bell's presence: 'Ein Wort wärmster Empfehlung. Eigentlich ist kein Wort stark genug, es zu seinen Gunsten auszusprechen. Ich rechne ihn mit Stolz zu meinen Freunden und danke dem Schicksal, dass es ihn mir zugeführt hat. Ich kenne ihn genau und stehe für diese Worte ein: Es ist eine der edelsten und bedeutendsten Persönlichkeiten, die mir in diesem Leben begegnet sind, einer der Menschen, die meinen Glauben an den Menschen aufrecht halten. Und nicht nur rein und bedeutend als Persönlichkeit, auch grundtüchtig, gediegen, vielversprechend als Philosoph. Schade dass seine Dissertation über Royce's Philosophie nicht zum Drucke kommen konnte, mit der er in Göttingen promovieren sollte. Die Fakultät hatte sie schon als 'valde laudabile' angenommen, das Examen rigorosum fand auch noch statt - in der Internierungsstätte (August I9I4!), nachher wurde es aber als rechtsungiltig erklärt: und so hatte Bell das Göttinger Doctorat regelrecht gemacht und ist nun doch nicht Doctor! Würde sich Harvard seiner annehmen und ihm eine Stätte der Wirksamkeit bieten, so hätte es an ihm eine treffliche Kraft, die herrlich auf die Jugend wirken würde'. Original letter housed in the Hocking Collection. Also published in Husserl, Briefwechsel, pp. I64-5. Husserl's letter, by Hocking's report, had a good effect, as Hocking soon wrote back to Husserl with news of Bell's hire at Harvard, writing: 'I was rejoiced at what you said of Bell; and your word came at the right moment'. Husserl, Briefwechsel, p. 167. 
both caught up in the Great War, nevertheless, if on quite different terms. While Bell was languishing in Ruhleben prison camp, allowed some study materials and correspondence but seriously restricted in what he could send out, Hocking was with the first detachment of American military engineers to reach the front in France. And while Bell was lingering in Germany reporting simultaneously for Reuters and British intelligence, Hocking was inspecting the courses used in army training camps.

Both men re-entered their academic careers soon after the war, but Hocking (more than Io years Bell's senior) moved quickly into the senior ranks of the Philosophy Department at Harvard, and Bell began as a junior member of the department with his now reinstated PhD. Bell's personal diary $^{1}$ (quoted frequently throughout these lecture transcriptions) reveals that they worked together as colleagues and socialised as friends.

It is not quite clear whether each of these colleagues took on the task of keeping notes in Whitehead's first course of lectures simply out of personal interest, or whether there were arrangements within the department to ensure that such courses of lectures would be recorded. Each of them recorded these lectures, however, in a quite different manner: with only a few exceptions, Bell seems to have made an effort to record the whole of each lecture, and has preserved a complete run of all 85 lectures; Hocking's notes by comparison begin at the end of October, miss out here and there, and provide only a partial account of some lectures. On a few occasions Hocking seems to have arranged with another junior member of the department, Ralph Eaton, to cover for him. At the end of Eaton's typescript of notes for 16 December, he left a personal message for Hocking:

Professor Hocking: I regret the meagerness of these notes, but find it impossible to listen and take a great many notes - The spirit of Whitehead is 'too wide a cosmos' to be got into notes. R.M.E. ${ }^{2}$

To some extent this must have been the reaction of anyone attempting to capture Whitehead's lectures in a page of notes.

Distinctive of Hocking's way of dealing with this challenge is his evident inclination to digest, organise and then record what are Whitehead's thoughts but also to arrange them in outline form in Hocking's own way. We can see this, of course, only because we now have Bell's notes with which to compare Hocking's. It is most heartening to find, therefore, that although Bell and Hocking often manage to capture material the other had failed to record, more often on key arguments, quoted phrases and pencilled copies of Whitehead's chalk drawings and so on, these two sets of notes support each other time after time, leaving us with the experience of reliving something quite close to Whitehead's original delivery.

1. Transcription of the 1924 diary by David Mawhinney, Bell Fonds, 8550/5/5.

2. See Hocking's notes for lecture 33 in this volume (page 147). 


\section{Louise R. Heath}

Louise Heath, by comparison, was still a graduate student at Harvard, taking her courses at Radcliffe College, and we know of no one else recording these Radcliffe lectures. What she provides, thereby, is Whitehead presenting what was formally regarded as the 'same' course of lectures at Radcliffe as were recorded at Emerson Hall. Heath was earning credit for 'Phil $3 \mathrm{~b}$ ' under the same rubric - 'The Philosophical Presuppositions of Science' as were the graduate student men taking the course on the same days. As Whitehead described for his son North, the Radcliffe lectures were 50-minute presentations at 9.00 a.m. each Tuesday, Thursday and Saturday, and the Emerson Hall presentations were each on the same three days beginning at noon. By comparing the notes taken at these two venues, we can determine, somewhat unexpectedly, that for much of the first semester each lecture given at Emerson Hall was then given at Radcliffe on the next class day (or even the one after), whereas for much of the second semester each lecture given at Radcliffe was the same (by and large) as given at Emerson Hall later that morning.

So, when Whitehead reports to North on 9 November that, after a Io-minute walk to Harvard Yard from Radcliffe, 'I then go to my room in the Widener Library - the University Library - and look over my notes for the 12 o'clock lecture and enlarge them', ${ }^{1}$ he is not describing how he is reviewing and adjusting notes for a lecture he had just given an hour earlier, but how he is refreshing the notes intended for the next lecture, now to be given for the first time at Emerson Hall. The implication is that he has at the very least prepared notes for a number of lectures in advance, and that (through much of the first semester in particular) Radcliffe lectures were ones he had already presented a class or two previously. These are suppositions to which we shall return.

Louise Robinson Heath (1899-1988) has left behind somewhat less evidence of her career than the two male note takers, but it is a career devoted throughout to women's higher education. We think this is the same person who graduated from Newton Public High School in 1917 and then attended Mount Holyoke as a 'Mary Lyon Scholar' (named for Mount Holyoke's founder) in Philosophy and Biblical Literature, and earned her $\mathrm{AB}$ in I92I. She was at Radcliffe from I92I or perhaps 1922 and completed her $\mathrm{PhD}$ there in 1927. In the preface to her one book, The Concept of Time (Chicago, 1936), Heath says:

It is evident ... that on this subject my thought has been very much influenced by Professor Whitehead. To him I owe thanks not only for sharing his thoughts on time but also for his time, both in class and in conference.

Her career from 1926 to 1947 was at Hood College, in Frederick, Maryland, while it was still an all-female institution; and then she was Dean at Keuka

1. Lowe, Volume 2, p. 295. 
College, an all-female institution on the Finger Lakes in New York State, from 1947 to 1954 .

Fortunately Heath preserved her notes from these 1924-5 lectures and at some point in her retirement (in the I970s perhaps) passed them along to Whitehead's biographer, Victor Lowe. What Lowe found were student notes - the notes of a graduate student to be sure, but designed for her own use, with all the limitations of someone unfamiliar with much of what was being said concerning mathematical physics and complex logical notation. That being said, they capture a remarkable amount in a consistent manner and, given the notes available from the Emerson Hall lectures, make possible some substantive comparisons between the lectures presented in these two venues.

\section{Three archival sources}

In 1988 Victor Lowe's literary executor, J. B. Schneewind, was left with the unfinished second volume of Alfred North Whitehead: The Man and His Work. ${ }^{1}$ Once Volume 2 was readied for publication in 1990, Schneewind declared in his Preface 'Thanks to [Lowe's] exhaustive investigations we know as much as it is possible to know about the life of a man who had the bulk of his papers destroyed'. Lowe himself, in the manuscript he had completed, mentions Louise Heath's notes from Radcliffe and also that there were some notes left by Hocking, but of Whitehead's own notes for these lectures Lowe explains:

He did not keep those notes. I have not found anyone who attended the lectures at Harvard [i.e. Emerson Hall] in I924-25, took detailed notes, and kept them. ${ }^{2}$

Fortunately, both men were wrong.

Even if Lowe had known about Winthrop Bell (there were those, after all, like Raphael Demos and Charles Hartshorne who had known him) it would have been challenging to track his papers to Nova Scotia. Bell had passed away there in 1965 and his papers had been sealed soon thereafter. They were destined to go to Bell's alma mater, Mount Allison University, the institution so well served by the Bell family. However, by the early I970s only Bell's books and a few other items had actually been received. It was known at Mount Allison that the remainder of Bell's papers were coming but, for reasons known only to the family, there would be delays. Portions only were released to the Mount Allison Archives between 1986 and 2004. So, even if Lowe (or anyone else at that time) had tracked down the possibility of Bell's legacy, it would have been unavailable.

Whatever the reason for the delay of so many years - in large part Bell's work with British intelligence - the Archives staff at Mount Allison University were finally able to organise and index seven metres of material

1. Lowe's Volume I of the Whitehead biography had been published in 1985 .

2. Lowe, Volume 2, p. I44. 
between 2003 and 2005, and by placing much of this description online ${ }^{1}$ made it possible for scholars to discover, in the first case, the only complete copy of Bell's dissertation, ${ }^{2}$ and soon thereafter the wealth of lecture notes he had retained both from his years in Göttingen and from the Whitehead and Woods courses of lectures at Harvard.

The notes on the Whitehead lectures were found in a rather innocentlooking folder containing about 90 pages tightly filled with handwriting in tiny script. Both sides of each page were used, occasionally even up the margins. Thanks to scanning (and then digitally enlarging and adjusting the contrast), and to the help and permission of the Archives, it has been possible to decipher this script and provide the transcriptions which set the baseline of information about these lectures - Whitehead's first ever lectures in philosophy.

Lowe may not have known about the Bell notes but he did point to Hocking's notes. 'On October 2I Professor Hocking began to attend the lectures. His notes from then to the end of the academic year may be found in Appendix I of Lewis Ford's Emergence of Whitehead's Metaphysics'. ${ }^{3}$ As Lewis Ford himself acknowledged, what he brought to publication in 1985 was only partial; of those completely transcribed he seems not to have appreciated that at least three were missing, nor that the larger number which someone had summarised were, at best, summaries of summaries. We were able to locate the full set of notes that were among Hocking's uncatalogued papers, as organised and left to the Houghton Library at Harvard by his son, Richard Hocking. Arrangements were made to have them scanned and permission gained to transcribe them from these originals and present them here in full.

Lowe also mentions the Heath notes. At some point, perhaps in the I970s, Lowe was able to contact her, and reports: 'Louise R. Heath kindly supplied me with her notes of Whitehead's lectures at Radcliffe that year'. ${ }^{4}$ These have never been published and since they are now held by the Center for Process Studies at Claremont School of Theology, within the holdings of the Whitehead Research Library, we have been able to transcribe these in full, as well.

1. See http://www.mta.ca/wpbell/.

2. Jason Bell had noted the listing for Bell's dissertation in 2009 and, knowing this might be the only complete copy still existing, arranged for a postdoctorate position at Mount Allison beginning in the 20IO/II academic year.

3. Lowe, Volume 2, p. I44. At the outset of his Appendix I, p. 262, Lewis Ford says: 'These notes of Whitehead's first course at Harvard were taken by one of his colleagues, William Ernest Hocking, and are here reproduced (in part) with the permission of his literary executer, Richard Hocking.... The lectures beginning with October 2I, I924 and ending March 28, 1925, have been summarized. The lectures beginning with March 31, 1925, and ending with May 26, 1925, because of their relevance to this study, have been put into publishable form without any major changes'. The beginning date of Hocking's notes, as it turns out, is I November. Only with Bell's notes by comparison (and a calendar) can one tell that Hocking misses three lectures in the set of notes Ford had transcribed in full.

4. Lowe, Volume 2, p. I44. In 1978, when Victor Lowe was at the Center for Process Studies (CPS) at the Claremont School of Theology as a visiting scholar, arrangements were made for a partial transcription of these notes with the assistance of Bruce Epperly, a graduate student employed by the CPS at the time. Our transcriptions have been completed directly from the originals, still held by the CPS. 
The results are revealed in the table of contents of this volume: thanks to the notes taken and kept by these three individuals, we are now able to present the Harvard lectures of Alfred North Whitehead, his first course of lectures for the academic year 1924-5. These include the course of lectures presented at Emerson Hall as they were recorded by Winthrop Bell and, since William Ernest Hocking was recording a good many of these same lectures, we have presented them both for each of these lectures. Louise Heath's notes were from the lectures presented at Radcliffe, so we have set out our transcriptions of these separately, and as her notes do not consistently distinguish individual lectures (as Bell's and Hocking's invariably do) we have grouped her notes by semester, distinguishing individual lectures as best we can and linking them to each of the Bell-Hocking lecture transcriptions to enable cross-comparison.

Whitehead's only other teaching for the 1924-5 academic year were his semester-long 'seminaries' and since Hocking has provided us with notes for at least a few of these, from October, we have presented transcriptions of them as well. Lowe speaks of the first-semester and second-semester seminaries, but does not seem to have realised the extent, particularly in the first semester, to which there was an overlap of those attending nor that their discussions intersected at a few points. ${ }^{1}$

Finally, the Appendix presents single pages from each of these sources taken from the same portion of the same lecture - to give a brief comparison of the three styles in their original form.

\section{Whitehead's lecturing style}

Lectures are by their very nature ephemeral; they are performances, and once over are gone. The score on which a conductor relies may persist, but that is not the same. By many accounts, Whitehead's performances were more like those of a conductor who only occasionally glanced at his score. There were no digital recordings captured by technicians, just handwritten notes taken by listeners; no archive of podcasts, just archival records documenting the occasion. Fortunately, we have some of these documents, but what we yearn for is to re-create the occasion. We have what a few listeners decided to write down and, insofar as it is possible, we can 'listen', through them, to Whitehead on the platform down front (Figures I and 2) and 'hear' him thinking through these issues and conveying his excitement and his conviction of their importance.

Lowe quotes Demos recalling 'a kind of oration' by the end of which 'the angels were singing'. ${ }^{2}$ That was his response to Whitehead's inaugural lecture, on 25 September, about a month after the crossing from old England to New England. Bell records in his personal diary, 'At noon - Whitehead's

1. In fairness to Lowe, at one point (Volume 2, p. I43) he wonders if the topics considered may have been quite similar, but this can now be demonstrated.

2. Lowe, Volume 2, p. I42. 


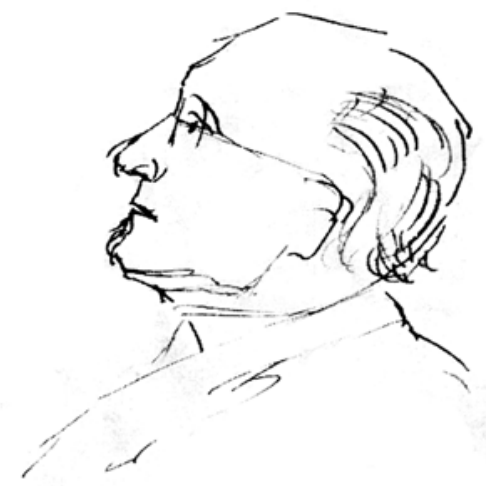

Figure I. A drawing of Whitehead by William Ernest Hocking (found with Hocking's notes on lecture 74, 30 April 1925)

first lecture - Very interesting. - All the Grandees there'. ${ }^{1}$ Lowe reports that not all the 'grandees' recall angel choirs, although dissenters were responding primarily to content. Whitehead was not known for a rich oratorical style but he certainly left many an audience with strong impressions. And one might suspect that the inaugural lecture was not going to be representative, since Whitehead will have wanted to prepare this one carefully; he probably read it out, or at the least kept closely to his score.

For almost 80 other performances, there are hints and suggestions that they were guided by notes drafted in advance, but not scripts read out to the class. Whitehead often commented at the end of one lecture where they would venture in the next, implying it had been prepared in advance; and he also paused occasionally, most often at the outset of another performance, to review the landmarks on the ground already covered. But there was no outline of the course handed out in advance, no syllabus in that sense, just the title and inaugural laying out of the kind of broad philosophical themes he would address.

We have quoted his letters to North explaining that between his two performances each Tuesday, Thursday and Saturday he would relax in his room in the main library and 'look over my notes for the 12 o'clock lecture and enlarge them'. As the earlier lecture at Radcliffe (during the first semester) was not the same one he was about to give at Emerson Hall, one can well imagine Whitehead looking over what was meant to come next, refreshing his intentions for the next 'movement'. Afterwards, 'We have Tea at about 4 to 4:30 in my study. (Callers don't want it.) After tea I read or write up lectures'. ${ }^{2}$ So, the impression given is that his notes were worked up in advance, but

1. Bell's diary entry for 25 September 1924 , Transcription of the 1924 diary by David Mawhinney, Bell Fonds, $8550 / 5 / 5$.

2. Lowe, Volume 2, p. 295. 


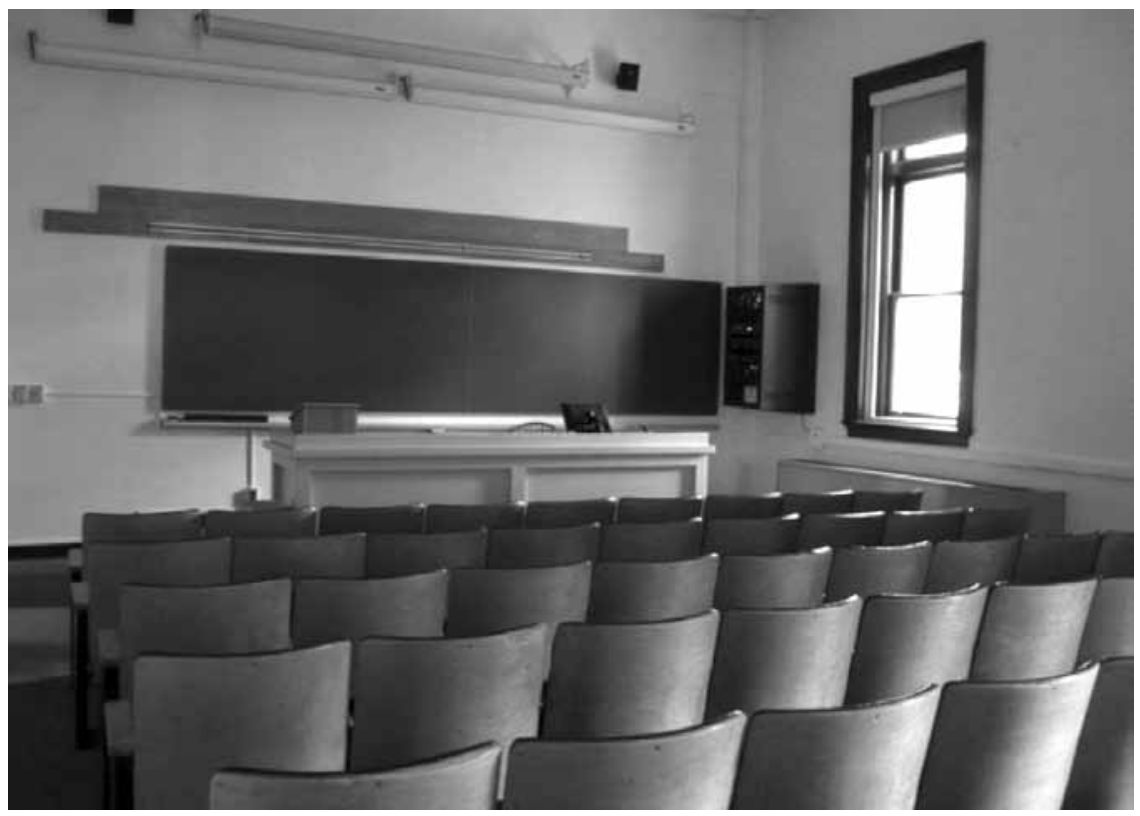

Figure 2. Whitehead's classroom in Emerson Hall (photograph by Ellen Usher, August 2008)

then reviewed, adjusted, enlarged and perhaps written up so as to incorporate what had been sorted out by thinking them through in and with his classes.

The number 80 was used above, because from the total of 85 lectures a few stand out as exceptions, and these exceptions might help us formulate the rule. Lowe was convinced that Whitehead was usually 'seated in a chair behind a table on the platform ... spoke to the class ... occasionally consulted what he had written down for his guidance'. ${ }^{1}$ And with considerably more evidence for $1924-5$ than Lowe had available, that still seems a good beginning. It is more difficult to discern in Hocking's consolidation of these lectures, although he sometimes marks direct quotes and notes Whitehead's asides; but in Bell's more complete scripting one can follow the flow, the pauses, the turnings of an oral presentation, and it leaves no imprint at all of being read out from a complete script.

One exception to that impression arises quite near the end, when Whitehead explains he wants to share with the class a paper on the history of mathematics he had presented the month before at Brown University. ${ }^{2}$ This is the same paper he mentions in the Preface to Science and the Modern World that was added to the Lowell lectures, which form the bulk of that

1. Lowe, Volume 2, p. I44.

2. The paper, 'Mathematics as an element in the history of thought', required two lectures (8I and 82) to present, on 16 and 19 May, about a month after it had been delivered to the Mathematical Society at Brown University. 
book, submitted for publication in July 1925. Hocking left no notes for the first of these two classes and only the briefest of notes for the second, but Bell's record of this paper being presented in Emerson Hall gives a quite different impression from most other lectures. The pace seems different - Bell has a hard time keeping up (or hearing) - and there are no diagrams on the blackboard. This one does seem like a paper being read out, which makes it the more evident that for most lectures one is not following a transcription that simply had been read to the class.

Another kind of exception are the occasions when it is clear that Whitehead is responding to questions. It is to questions from Demos that Whitehead says he is responding in the spring ${ }^{1}$ and on two Saturdays in the autumn ${ }^{2}$ when he says he is setting aside the lecture he had planned in order to deal with questions that had come up the previous evening - which must have been his Friday evening 'Seminary'. He had told North that those occasions were conducted quite differently from his course of lectures. 'I usually start the discussion, and intervene at irregular intervals'. The Saturday midday lectures that were set aside seem to be a kind of carry-over and may even have involved the same people. The implication is that the Friday evening seminaries were considering many of the same issues, so much so that it made sense to bring those discussions into the lecture classroom as a way to review and clarify what Whitehead had been trying to express. And thereafter, he would return to his solo performances, thinking aloud through the next set of issues.

The one other exception, surely the most marked exception and rather the 'elephant in the room' for this whole academic year, is the elephant known as the Lowell lectures. There is surprisingly little mention of them in his Tuesday, Thursday, Saturday scheduled lectures. They do, though, present a clear contrast in mode of presentation. The Lowells, there can be little doubt, were fully written out, and in delivery he must have simply read them aloud. Lowe details the circumstances of the invitation from President Lowell to deliver a series of eight lectures, in March 1924, which means after Whitehead had accepted the new appointment to Harvard but well in advance of his actual departure - time enough to try out some ideas. He proposed a preliminary title, 'Three centuries of natural philosophy', which suggests the chronology of the first six chapters we find in Science and the Modern World was already firmly in mind before he even crossed over to New England. He also consulted about the appropriateness of composing these lectures with the eventual book clearly in mind. Whitehead wrote to his son in December 1924 that he was bearing down on the task of writing out these lectures, and wanted them completed before the series began at the beginning of February. He later exclaimed it was like writing a whole book in two months. ${ }^{3}$

1. See lecture 74 (30 April).

2. See lectures II and 23 (I8 October and is November).

3. The first comment was in his letter of 2I December 1924 (reproduced in Lowe, Volume 2, p. 30I); and the second was from I5 March 1925 (reproduced in Lowe, Volume 2, p. 303). 
The overall strategy of his course of Harvard lectures may also have gelled for Whitehead as had his Lowell lectures, well in advance. It is difficult to tell, but each lecture seems at most to have been sketched out and if written out, only afterwards. What we can see is that the chronology of the Lowells would not serve as the framework for his 'Philosophical Presuppositions of Science', a comparison we will consider in the next section, except to say here that it also seems clear that the course of lectures was not a preliminary run through for what would become Science and the Modern World. It certainly was the occasion for Whitehead to think carefully through those very issues, but that did not mean the overall outlines needed to be the same, and while the Lowells were written quite intentionally to appear in print and to be read out in advance as a preview for his Lowell Institute audience, his course of Harvard lectures was left open enough to become a genuine philosophical exploration.

Despite these two sets of lectures both dealing with the themes of most interest to Whitehead at this point in his philosophical development, he makes no mention of the Lowells in his course of Harvard lectures. He mentions the Lowell lectures of Russell and others but not his own.

There is one exception, however: a unique case that arises in the latter half of a lecture he delivered mid-April. ${ }^{1}$ Hocking records a sequence of objections to 'subjectivism' but leaves no indication of Whitehead's mode of delivery, whereas Bell records the same objections but states quite clearly, in brackets, that Whitehead was reading at this point: '[Whitehead reads a lot, excellent, from Lowell Lectures.]' Once we are told - and it is Bell who tells us, not Whitehead - that these objections can readily be identified with chapter V of Science and the Modern World, on pp. 89-9I. This is a most unusual case where we know Whitehead was reading, and from the same script he had already read out at the Lowell Institute, intended for print; it is a clear exception helping to prove the rule: speaking his thoughts aloud from a rough set of notes.

One final consideration that bears on classroom performance is the extensive use Whitehead made of the blackboard. This was a teaching tool Whitehead must have been using for the 40 years since he began teaching mathematics, and used extensively in applied mathematics as well. We now find Whitehead making frequent use of the blackboard during these philosophy lectures. (We need hardly point out that one does not use the blackboard sitting down, nor likely when reading from a fully written out script.) We find equations, symbols, logical notation, small doodles, examples from physics; even leaving mathematics and logic aside, there are 129 of these from Bell's notes. And lest one puzzle over whether some of these are Bell's own, or at all accurate, they match up favourably with most of the IO4 recorded by Hocking, and are identifiably similar even to the 73 recorded by Heath from Radcliffe. Some of these chalk diagrams are quite detailed, quite

1. Lecture 7I (I6 April). 
complex and, we would argue, quite significant. Although a few diagrams are to be found in Process and Reality and Part III of An Enquiry Concerning the Principles of Natural Knowledge, those ones accompany his descriptions from physics. Many of the diagrams to be seen in this volume provide a vivid sense of how Whitehead himself pictured the relationships he argued were fundamental, and a spatial pattern depicting events and objects emerging through time.

While there are no self-referencing comments by Whitehead about his own lecture style, about his speaking voice or about sitting down (there are one or two references to his chair), there are many instances where chalk becomes the point of an example. The chalk seems always to be at hand. And there are many references to his reliance on diagrams. Many are the warnings that his audience should not take these as anything more than clumsy reminders, pointers. They are not to be taken as the truth; they are sometimes said to be 'silly'. But he does also defend their frequent use by saying, for instance (while chalking up a particularly complex example): 'Recourse to diagram rather than long verbal statement. Diagram is mathematicians' analogue to Plato's myth. (Whitehead can't make up myths!)' ${ }^{1}$ We take that to be Whitehead's commentary on himself: I can't do myths, but as a life-long mathematician I can do diagrams!

Somehow this repeated stepping up to the blackboard seems emblematic of a lecture style in which Whitehead is thinking out loud, in front of the room, gesturing with a piece a chalk, demonstrating a young boy catching a cricket ball, and turning to the board to fill it with logical notation, mathematical equations, or remarkably adept Minkowski-like diagrams of the spread of space and the flow of time.

\section{Content of Whitehead's lectures}

Whitehead presented his class with no roadmap of where this course of lectures was going. The title and his inaugural lecture signalled the sort of issues he intended to address, however successfully those were absorbed by either students or colleagues, but there was no printed outline, no syllabus handed out. Nevertheless, it would be too hasty to conclude Whitehead was making it up as he went along. The topics he intended to consider were quite clearly those explored in Principles of Natural Knowledge, The Concept of Nature and The Principle of Relativity. He says so openly, referring to them often, assigning portions as readings and for essay assignments, along with frequent references to the work of colleagues, many of whom were the same as referenced in these former works, or thanked in his prefaces.

Whereas Principles of Natural Knowledge introduces his concept of 'extensive abstraction' in Part III, and The Concept of Nature picks up this

1. From lecture 39 (13 January). Notice that the note-taker, Bell in this case, cannot use the first-person pronoun, so we are left to struggle with transcriptions in which Whitehead oddly refers to himself in the third person. 
method in chapter IV, within this I924-5 course of lectures Whitehead holds this topic back until the beginning of the second semester, where it frames the development of his second semester of lectures, and in just this sense the first-semester lectures are devoted to the topics of Principles of Natural Knowledge Parts I and II, and the opening chapters of The Concept of Nature. Similarly, he introduces topics from Part I of The Principle of Relativity and he makes at least brief references to the more technical matters developed in Parts II and III.

This is not to suggest that the first semester is simply a review of the preliminary chapters of his previous work. And we are warned, as were his students, ${ }^{1}$ that Principles of Natural Knowledge was 'obviously by someone immersed in mathematical physics'. In that work, he had 'let himself be fooled' and was often 'confused', 'did not bring that out well', or handled the matter too 'clumsily'. As he acknowledges throughout the year, he had often been 'in a muddle'. In Concept of Nature he was held back because he 'had not [a] full theory of Mentality then'. When he does turn to the method of extensive abstraction in the second semester, his introductory remarks warn: 'Not so concerned now in following systematic details, as in pointing out confusion in [all three] books ... pointing out what lies behind ideas there'.

The topics addressed in this course of lectures were ones Whitehead had been mulling over for some years, but the lectures would be an opportunity for him to address earlier confusions and for him to introduce new insights. He had long been attracted to the philosophical challenges presented by presuppositions evident throughout modern science, but this course of lectures begins with a tighter focus on the scientific developments Whitehead had himself witnessed and the revolutionary new insights which he and colleagues he knew personally had uncovered. Maxwell's mathematical treatment of electromagnetism, Thomson's discovery of the electron, the rise of quantum theory and then relativity are quickly laid out for these unsuspecting students of philosophy. 'These lectures not philosophical', Whitehead explained, 'but to get Science into form in which one can expect Philosophers to understand it'. ${ }^{2}$ Even so, it is quite remarkable that - as he reports to North - if anything, the numbers attending were growing. ${ }^{3}$

The inaugural lecture had introduced the alternative conceptualisations of a world characterised by continuity and that undergirded by atomism. His early lectures, presenting four decades of revolutionary science, had provided support for both of these and amplified the tension between them. Whitehead's growing conviction, openly shared, was that we are not confronted here by the choice between what seem to be radical alternatives,

1. The words and phrases quoted in this paragraph are respectively from lectures 80 (I4 May), 58 (I7 March), I9 (6 November), 4I (I7 January), 38 (Io January), 43 (Io February), 59 (I9 March), 8 (II October), 37 (I4 May), 74 (30 April) and 43 (Io February).

2. See lecture 3 (30 September).

3. Lowe, Volume 2, p. 298. 
but by the challenge to unpack their underlying assumptions and articulate them within a metaphysical synthesis that enables a balance between them.

From his own experience with recent science Whitehead immediately turned to his other essential resource, the figures in the history of philosophy to whom he had recourse again and again. But here we are asked not only to consider Hume (as in his previous books) and the scepticism that left induction impossible to justify, but also to attend to Kant and Whitehead's conviction that the resolution of the former will require turning Kant on his head. He had suggested previously that the roots of Hume's problem are to be found already in the Greeks, but in addition to Plato these are now more narrowly identified with Aristotle's analysis of substance-attribute, which leads to the subject-adjective presumptions that become embedded in modern subjectivism. Even more striking is Whitehead's acknowledgement that the means for avoiding this philosophical dead end is also rooted in Aristotle - in his analysis of becoming as arising from potentiality. For all that we recall of the pedestal on which Whitehead places Plato, and the missteps he attributes to Aristotle, in these lectures he says, despite the 'unfortunate ... bias he gave to Logic', Aristotle is 'the greatest of all Philosophers all the same'!1

From these two resources Whitehead is prepared, by the beginning of November (about the time Hocking joins with Bell in attending and keeping notes), to begin a 'somewhat more Systematic consideration'. As he declares: 'you've got to see the Wood by means of the trees, you know.'. The wood he begins to articulate includes many of the implications he had already drawn from the needs of the new science, but his students would not have been in a position to appreciate just how new were his injection of not just 'events' and his own portrayal of 'objects', but a new focus on 'occasions' and the need for 'ingression', even the need for (not subject) but 'superject'. These concepts are known to us only because we recognise them as surviving into his later books.

We also find him musing over whether 'expansional' might better describe the core characteristic of his own metaphysics, rather than 'processional', and whether the insights he is determined to bring in from the biological sciences could better be articulated as a 'philosophy of evolution' than a 'philosophy of organism'. A particularly striking instance of trial runs that do not survive is Whitehead attempting to build off the Humean notion of 'impression' - he is, after all, determined to adhere to the empiricist assumptions he shares with Hume - where for a series of lectures he expresses his own insight as the 'impress' (the mode of interaction between events). Eventually he turns away from this trial run and turns instead to 'prehension'. By 23 November, Whitehead declares in a letter to North: 'I am gradually feeling my way into a metaphysical position which I feel sure is the right way of looking at things'. ${ }^{3}$

1. See lecture 72 (I8 April).

2. See the beginning of lecture 17 (I November).

3. Lowe, Volume 2, p. 298. 
By December and carrying over to the final weeks of the first semester in January, Whitehead is no longer ploughing new ground, but thinking through an appropriate overview of what presuppositions have been unearthed and articulated. He explores the insights which physics should consider borrowing from biology. And, once again, he revisits the great alternative approaches of starting either from the immense permanences with which modern science has been enthralled - a 'Metaphysical fairy-tale', as he once called it $^{1}$ - or with the insights to be gained by beginning from change and generation. Curiously, he ends his first-semester lectures by looking back to the early modern assumptions of Galileo and Newton. At the same time (as he told North) he was composing his Lowell lectures, which become the core historical chapters of Science and the Modern World and which begin with Galileo and Newton and work their way century by century towards quantum theory and relativity. In contrast, in this 1924-5 course of lectures he proceeded the opposite way around. Clearly, the Phil $3 \mathrm{~b}$ lectures were not simply a trying out of the new Science and the Modern World sequence, even while they were an exploration of the very themes and concepts Science and the Modern World and even Process and Reality will later deploy. We have the opportunity in these lectures of following along as he tries out some of the new concepts he will later adopt, and also try out some possibilities that he will decide to drop.

What then of the second semester? Before the teaching term began, on Io February, he had already launched into his Lowell lectures each Monday and Thursday at 5 p.m., just off Commonwealth Avenue in Boston's Back Bay. These continued through the remainder of February, and his Radcliffe and Emerson Hall lectures during this same period shifted back into an introduction to the logic found in the first few sections of Principia Mathematica. According to Lowe's account of Whitehead's second-semester 'Seminary on Logic' he was, perhaps even by student request, beginning with similar material there. It is tempting to suppose that while the Lowells were being presented, Whitehead had made his regular teaching duties a bit easier for himself.

The construction of symbolic propositions developed throughout February set the stage for a quite intense consideration of what the method of extensive abstraction (as first presented in Principles of Natural Knowledge and Concept of Nature) could achieve, and a comparison of the possibility of a geometry of space based on junctions, boundaries of volumes and the relation of 'extending over' as an alternative to the simpler pathway built on points. As with The Principle of Relativity we see Whitehead's openness to the implications of special relativity, and particularly the re-conceptualisation of 'simultaneity' that it requires, but also a deep resistance to time being folded into the fourth dimension of space. ${ }^{3}$ Time remains, as it must for Whitehead, distinct; even

1. See lecture 30 (4 December) and also 32 (з December) on 'permanences'.

2. Lowe, Volume 2, pp. 147-8.

3. By comparison, nothing of his alternative conceptualisation of gravity to Einstein's general theory of relativity is presented. 
so, the Minkowski-like portrayal of events embedded in a time-cone is shown to hold out exciting possibilities for a Whiteheadian interpretation.

By early April Whitehead is articulating a 'temporal atomism' imposed partly by developments in science and partly because it makes possible his philosophy of organism. This has been remarked on before, most notably by Lewis Ford, who made the lecutre of 7 April $^{1}$ a focal point of his claims for a turning point in Whitehead's metaphysics. ${ }^{2}$ Ford's Appendix I contains the only other publication of the Hocking notes from these lectures, as we have acknowledged, and since his full transcriptions begin at the end of March, that enabled him to capture the leading lines from 7 April. But we can only assume that without any Hocking notes before the beginning of November, Ford missed Whitehead's setting up of the challenge of finding an adequate way to interweave atomism with the continuity also required for any process philosophy.

'The real point', as Whitehead clarified on 9 April, 'is how to deal with this balance of Atomism and Continuity'. ${ }^{3}$ With only summaries through February and March, Ford seems to have missed Whitehead's building up to an insight he had already anticipated. What was openly declared by Whitehead on 7 April was part of the overall trajectory of this course of lectures from its very beginning. Similarly, while Ford picked out Whitehead's acknowledgement of a definite 'muddle' enveloping these issues, full access to the Bell notes (or even fuller access to the Hocking notes) might have warned him that Whitehead was professing a muddled state on many matters, leading all the way back into his previous publications.

This Introduction may not be the appropriate place for a serious analysis of Lewis Ford's The Emergence of Whitehead's Metaphysics: 1925-1929 (1984), but he has left us with a misapprehension of how this course of lectures was organised, one we feel compelled to dispel. The tunnel vision induced by reliance on Hocking's notes shows itself as well when Ford turns to the chapter on abstraction in Science and the Modern World. 'According to W. E. Hocking's notes, the term "actual occasion" was first used in Whitehead's lectures for April 30, 1925'. ${ }^{4}$ A correlative concept with that of 'eternal object' which (as Ford correctly notes) was the central issue of the chapter on abstraction, Ford notices in the Hocking notes the careful attention to this topic in, apparently, the lecture of 22 May. However, while Hocking had marked his set of notes at 22 May, a calendar plus Bell's notes and diary - Heath's notes do not help, since they are not consistently dated, and match the Emerson Hall lectures only roughly at this point - make it clear that Hocking actually took these notes on 2I May. Hocking was absent for the class on 23 May or Ford might have noticed that these two lectures,

1. See lecture 67 (7 April).

2. Lewis Ford, The Emergence of Whitehead's Metaphysics: 1925-1929 (New York: SUNY, 1984), pp. 5Iff.

3. See lecture 68 (9 April). This same point does not get recorded in Hocking's notes for the same lecture.

4. Ford, Emergence, p. 67. 
together, ${ }^{1}$ are clearly an anticipation of what becomes chapter X in Science and the Modern World, 'Abstraction'. That is what Whitehead says these lectures are going to address, or, more pointedly, they are 'considering things from the point of view of Eternal Objects rather than from that of actualities'. More importantly, what Ford could not have realised was that both 'eternal objects' and 'actual occasions' had been introduced by Whitehead in his October lectures, and were being treated specifically in these terms already in the lectures of early November. ${ }^{2}$

In all these cases, the lectures were so organised that Whitehead had already introduced most of his more forward-looking concepts by the end of October and refined them more systematically during November. Then as the second semester constructed a propositional framework not only for systematising geometry but also for undergirding the metaphysical vision Whitehead was still developing, many of these key concepts were bought back into his lectures as he sought to demonstrate their collective coherence. It misconstrues the trajectory of these lectures to focus on any one of these key concepts as coming into play for the first time this late in the academic year.

It is relevant to point out, and perhaps even deeply important to appreciate that Whitehead paused in the midst of the concentrated work of the March lectures to consider methodologically the role of 'hypothesis'. This seems to have been not just a procedural step essential within the sciences, but equally typical in metaphysics, where one needs to articulate, Whitehead suggests, the vague apprehensions we develop into hypotheses. Here we have a critical indication that there is no hard and fast boundary between where scientific theory, natural philosophy (or, as Whitehead sometimes termed it, cosmology or the natural order) and metaphysics either begins or ends.

Whitehead's own hypotheses led him finally to what he had warned was still missing in Concept of Nature: a theory of mentality. This provides a particularly clear example of the pattern we have suggested can be seen across this course of lectures. At several points in his lectures through November into December he pointed ahead to the possibility and need for cognition. But not until the last two lectures in April does he return to it, saying: 'To avoid [yet another] muddle now need a point kept in background so far'. Cognitive experience was the point he had not yet developed: 'how Cognition looks sticking close to point of view developed so far in this course'. No one familiar with Whitehead's later publications will be surprised by what one finds in these two lectures. ${ }^{3}$ The mind must be recognised as 'imaginal', rather than images mental. But in the context of this course of lectures it is interesting that he waits to develop 'how Cognition will look', till this later

1. See lectures 83 and 84 in this volume.

2. The term 'occasion' is introduced by $2 \mathrm{I}$ October (lecture I2) and as 'actual occasion' from 4 November (lecture I8), whereas he is considering the role of the 'eternal' by 30 October (lecture I6), 'eternal existent' on 8 November (lecture 20) and 'eternal object' - and consistently thereafter - by 13 November (lecture 22).

3. See lectures 73 and 74 (28 and 30 April). 
point of the course, not as something new, but long recognised by him as the precursor he needed to take the next and final step.

The 'Test of self-consistency of an ontology is its possibility of giving place to Epistemology'. ${ }^{1}$ Whitehead openly acknowledged that his was not a widely held conviction, that one should not, philosophically, begin with epistemology. He would have agreed that the issues philosophers confront in epistemology are tremendously important, but the way to begin is with metaphysics:

Whitehead [read this in the first-person!] objects to point of view that first step in Philosophy is an investigation into powers of human mind (How Knowledge is possible). You can't express yourself until you have a certain minimum of ontological doctrine. ${ }^{2}$

As he had argued already in the autumn, he 'repudiates Epistemology as the one foundation of metaphysics. But it's the first source and Critic of the Metaphysics' ${ }^{3}$

So, while metaphysical hypotheses need to be developed first, the first test of such hypotheses will lie in the epistemology they make possible. It stands as a remarkable feature of this whole course of lectures, which began with Whitehead teasing out the presuppositions exposed by the revolutionary changes in the science of his day, then working through those possibilities against the greatest philosophical minds he could resurrect, followed by an attempt at systematising what he had uncovered into a coherent system, and then, nearing the end of the course in early May, the testing of his system against the epistemology his ontology could provide. However one judges the results of this testing, it was a remarkably self-conscious, self-critical assessment of where his philosophical work stood, tested directly in front of his colleagues and students.

Whitehead's final lecture seems a particularly apt opportunity for a final comment. Ford had noticed the rather oddly timed return to considerations of Newton and Einstein, but even in Hocking's notes he might have noticed that this return is prompted by a discussion of the experimental results of work by Miller on the top of Mt Wilson. (It is not surprising that there is no mention of this in Lowe, since the Heath notes from Radcliffe do not include this last lecture at all.) Dayton Miller was an American physicist known for holding onto the aether theory and resisting Einstein's theory of relativity. Miller worked with Edward Morley to improve the sensitivity of the Michelson-Morley apparatus, and continued to refine these techniques for many years, claiming he could obtain results indicating aether drift. In I926 Miller published results in the Physical Review of measurements he had made at the top of Mt Wilson during 1925 and which he had already announced that spring.

1. The opening statement of lecture 76 (5 May).

2. See lecture 76 ( 5 May).

3. See lecture 29 (2 December). 
Whitehead saw this announcement as an irresistible opportunity to share with his class an example of science in the making. ${ }^{1}$ Here was the kind of scientific work which exposes underlying assumptions and therefore the occasion to review one last time the kind of presuppositions his whole course of lectures was organised to explore.

\section{Editorial handling of the lectures}

A full list of the editorial principles for the entire Critical Edition is given on pages xiii-xv. These have guided the work of this volume and are intended to guide the editorial effort behind what will become several volumes of Whitehead's Harvard lectures. In addition, there are considerations which apply specifically to this volume and to the handwritten material we confronted.

- Lecture numbers. The 85 lectures Whitehead gave at Emerson Hall during the I924-5 academic year have been numbered consecutively, as this proved to be the only reliable and unambiguous means of identifying each. None of the persons who took and kept notes for these 1924-5 lectures attended every lecture, and though most lectures were dated this was not always accurately done. It was possible to establish how many lectures there were only by checking across all three sources; and it does seem, fortunately, that from all these sources we have at least some record of each lecture. Bell also kept a personal diary, which has proven to be an essential additional source of information, and where appropriate has been quoted in the editors' notes to the lectures. From institutional records we only ever found general listings of the courses offered in the Philosophy Department ${ }^{2}$ for that year and little else.

- Page numbers of originals. Since no attempt has been made to retain original page length, and since each of the handwritten pages of notes had been numbered - through the full year for Bell's notes, through each semester for Heath's notes, and dated-numbered by Hocking - we have inserted these numbers (for example $|23|$ ) to provide a clear indicator for whenever one might wish to check the transcript against the handwritten originals.

- Retained look, layout and line breaks. Bell's handwriting is so small, and fills most of his pages, that it has not been possible to maintain much indication of the layout of his transcription in this printed version, but we have endeavoured to give a rough impression at least of the layout of both Hocking's and Heath's notes. Thus, for example, where Bell breaks for a few lines into two columns this has been retained, and for Hocking

1. It is difficult to know for sure, but lecture 85 (26 May) almost seems like an extra added on. It was not even given at Radcliffe. And the opportunity to examine the implications of Miller's claims seems a more likely explanation than Whitehead having long planned to end the course on this note.

2. Course listings for the Philosophy Department can be found, after the fact, in the Reports of the President and the Treasurer of Harvard College, which are reproduced at http://pds.lib.harvard.edu/ pds/view/2574586?n=6828; and for Radcliffe at http://pds.lib.harvard.edu/pds/view/34299933?n=2547. 
we have sought to maintain the outline style he created. Similarly, the use of arrows, lines and odd spacing has been retained insofar as it has been feasible, because it seems an underlying feature of how each attempted to capture what was an oral presentation. Marginal marks have similarly been included.

- Lack of punctuation. Following directly upon the last point, we have introduced more standard punctuation only where confusion might arise, but have otherwise retained lack of punctuation, excessive use of dashes, extra spaces and so on, all in an effort to not lose the pace and flow of Whitehead speaking.

- Placement of diagrams. In a similar way, we have not only worked to retain the sketches and diagrams each attempted to copy from the blackboard, but also to retain the relation on the page with its most closely associated comments, since they are often Whitehead's oral clarification of what his chalk drawing was meant to convey.

- Rendering of non-text items. The mathematical equations, symbols, logical formulae (in Principia Mathematica notation) and Greek with accents are all typeset reproductions of the handwritten original, whereas the sketched diagrams are digital scans taken from the original page, enhanced to improve contrast, erase overlapping text and decrease the interference from text leaking through from the opposite side of the page, and finally replaced on the now transcribed page.

- Abbreviations. Contractions and abbreviations were encountered in all three sets of notes, and are particularly rampant in Bell's notes, according to a shorthand of his own devising. As stated in the list of general editorial principles, our intention has been to expand all abbreviations and most contractions, silently, and to comment on them in notes (as with other indecipherable terms) only when all else failed.

- Angle brackets. As each original course of notes makes use of both parentheses and brackets, we have signalled our own editorial insertions using 〈angle brackets). We have attempted to keep this 'noise' to a minimum, opting to use footnotes instead.

- Footnotes. In addition to footnotes being used to clarify editorial issues with the text, they have also been used to share information prompted by items that arise in the content of these lectures. Most often these are people, publications, poems or events familiar a century ago. Our objective has been to clarify and identify but not to engage in scholarly interpretation. Thanks to Lowe's biography, the Stanford Encyclopedia and online search tools, this has been possible, but we have stopped short of tying these references even to other of Whitehead's publications let alone secondary literature. They are intended to invite further research, not to forestall it. 


\section{Acknowledgements}

In addition to the support and sources listed in the General Editor's Acknowledgements for the Critical Edition (page xvi), this volume would not have been possible without access to the three major sources on which it has drawn:

- The original pages of notes by Winthrop Pickard Bell have been transcribed and published here with permission. Winthrop Bell's original Alfred North Whitehead lecture notes for Philosophy $3 \mathrm{~b}$ at Harvard University, 1924-1925, were found in the Winthrop Pickard Bell Fonds $-650 \mathrm{I} / \mathrm{I} / 2 / 8$ and were supplied compliments of the Mount Allison University Archives - Sackville, New Brunswick, Canada.

- The original pages of notes by William Ernest Hocking are used here with the permission of Houghton Library, Harvard University, Cambridge, MA. The folder of original notes were found in the uncatalogued collection 92M-7I, Box 3, Houghton Library, Harvard University.

- Due diligence did not reveal any heirs of Louise Heath, whose original pages of notes are owned by and published with the permission of the Center for Process Studies, Claremont School of Theology, Claremont, CA. The original artifacts are archived as Whitehead Research Project, Center for Process Studies, STUoo4.

The Heath notes had already come to the Center for Process Studies when this overall project began, and while it had been known that Hocking, too, kept notes (and these had been published in part as Appendix I to Ford's Emergence) the editorial team sought out and found the folder of notes kept by Hocking and deposited by his son, Richard Hocking, in the Houghton Library.

This was prompted by Jason Bell (no relation) discovering in 20IO-II that Winthrop Bell had also taken and retained notes from these lectures. They were located amongst Winthrop Bell's papers that had only recently been organised, described and placed online (see http://www.mta.ca/wpbell). This had been accomplished by the Mount Allison Archivist, David Mawhinney, who has continued to support this project through the intervening years. No one knows Bell's biography better, and his transcriptions of Bell's personal diary, for example, have enriched the backdrop to this story.

An extra note of gratitude is owed to Jason Bell for recognising the unusual quality of Bell's notes, for getting the ball rolling, and early draft transcriptions of challenging handwriting, and who has served as co-Associate Editor. Through Jason Bell support was provided by the Social Science and Humanities Research Council of Canada during the early stages of recovering Bell's handwritten notes. A special word of thanks is also owed to Joseph Petek, the master of the materials now held in the Whitehead Research Library, whose tireless efforts to draft and recheck transcriptions of Hocking's and Heath's handwriting, tease out administrative mysteries and directly assist in 
salvaging hastily sketched diagrams (despite the intervening continent) have proven invaluable every step of the way.

Technical challenges lay in store that ranged from logical notation, relying upon a symbolism no longer actively utilised, to mathematical equations utilised only within physics, and Greek terms carrying classical accents. These were all dissolved with expert assistance from Nick Griffin (for whom Principia Mathematica is still ever present), Ronny Desmet (with expertise in applied mathematics and a keen interest in the Whitehead years leading up to Harvard) and my colleague Bruce Robertson, who not only corrected my corrupted Greek but also solved some linguistic mysteries. Indeed, each of these generously offered assistance and advice well beyond my plea for help.

It was George Lucas and Brian Henning who immediately recognised how unusually informative were the notes and sketches left to us by Bell, which along with those from Hocking and Heath could make for so valuable a volume of material from the first of Whitehead's Harvard years. They have encouraged, guided and supported this first volume throughout.

Finally, a personal moment to acknowledge how wife and family have watched over the retired professor, still at work when it was time to be out at play. 
'I am gradually feeling my way into a metaphysical position which I feel sure is the right way of looking at things. I am endeavouring to get it across ... in lectures.'

A. N. Whitehead, letter to his son, North, 23 November 1924 
